\title{
INTERFACIAL WATER AT SYNTHETIC AND NATURAL LIPID BILAYERS PROBED BY VIBRATIONAL SUM-FREQUENCY GENERATION SPECTROSCOPY
}

\author{
F. Cecchet \\ Laboratory of Lasers and Spectroscopies (LLS), Namur Institute of Structured Matter (NISM) and \\ NAmur Research Institute for LIfe Sciences (NARILIS), \\ University of Namur (UNamur), 61 rue de Bruxelles, Namur, B-5000, Belgium \\ e-mail: francesca.cecchet@unamur.be \\ Submitted November 13, 2019 \\ Accepted May 22, 2020
}

\begin{abstract}
Background: At lipid interfaces, water plays a crucial role in carrying biological processes, so that there is a huge interest in unravelling the behaviour of water close to membranes. At charged bio-interfaces, water dipoles form an organized layer. Probing such an interfacial thin layer buried between macroscopic bulk environments is a real challenge. Vibrational sum frequency generation (SFG) spectroscopy is intrinsically specific to interfaces, and has already proven to be an ideal tool to investigate model membranes and their surrounding water.
\end{abstract}

Objectives: The goal of this work is to measure the vibrational SFG response of interfacial water around different model membranes - from easiest synthetic lipids to more complex natural lipids, — in order to use it as diagnostic signal able to distinguish the lipid bilayer interface by its charge properties.

Materials and methods: Lipid bilayers made either of synthetic or natural lipids (Avanti Polar Lipids) were physisorbed on $\mathrm{CaF}_{2}$ prisms (Crystran), by using the method of the spontaneous fusion of lipid vesicles, to form so called solid-supported lipid bilayers (SSLBs). The model membranes were investigated by SFG spectroscopy at the solid/water interface.

Results: The SFG response was measured between $3600 \mathrm{~cm}^{-1}$ and $2800 \mathrm{~cm}^{-1}$, where $\mathrm{OH}$ stretching vibrations of water molecules show-up. The SFG intensity of the $\mathrm{OH}$ peak maximum at $3125 \mathrm{~cm}^{-1}$ was recorded during the adsorption of lipid vesicles on the surface, and provided knowledge of the changes of the charge properties of the interface due to the adsorption of the model membranes. The SFG signal indicated that the organization of water was larger at negatively charged than at positively lipid interfaces, and reached the highest value with natural E. coli cardiolipin layers. Moreover, when the full composition of natural lipids was unknown, the behaviour of the SFG response enabled establishing the charge characteristics of the corresponding lipid interfaces.

Conclusion: The SFG response of water enabled estimating average charge behaviour of synthetic and natural lipid bilayers in pure water, thus paving the way to use the SFG signal of water as new diagnostic tool to identify lipid interfaces.

KEY WORDS: water; lipid membranes; nonlinear optics; sum-frequency generation; vibrational spectroscopy.

\section{МІЖФАЗНА ВОДА В СИНТЕТИЧНИХ І ПРИРОДНИХ ЛІПДНИХ БІСЛОЯХ ЗА ДАНИМИ КОЛИВАЛЬНОЇ СПЕКТРОСКОПІЇ $З$ ПІДСУМОВУВАННЯМ ЧАСТОТИ Ф. Kecce \\ Лабораторія лазерів і спектроскопї, Інститут структурованої речовини Намюра, Науково-дослідний інститут природничих наук Намюра, Університет Намюра, вул. Брюссельська, 61, Намюр, В-5000, Бельгія}

\begin{abstract}
Актуальність. Вода відіграє вирішальну роль в протіканні біологічних процесів на ліпідних міжфазних межах, тому існує величезний інтерес до вивчення поведінки води поблизу поверхні мембран. На заряджених міжфазних межах диполі води утворюють організований шар. Зондування такого тонкого міжфазного шару, що знаходиться між макроскопічним об'ємним оточенням, $є$ реальною проблемою. Коливальна спектроскопія 3 підсумовуванням частоти (КСПЧ) є по суті специфічною до міжфазних меж і вже довела, що є ідеальним інструментом для дослідження модельних мембран і навколишньої води.
\end{abstract}


Мета роботи. Мета даної роботи - виміряти методом КСПЧ коливальний відгук міжфазної води навколо різних модельних мембран, від найпростіших синтетичних ліпідів до більш складних природних ліпідів, щоб використовувати його в якості діагностичного сигналу, здатного розрізняти поверхню розділу ліпідного бішару за властивостями ії заряду.

Матеріали та методи. Ліпідні бішари, виготовлені з синтетичних або природних ліпідів (Avanti Polar Lipids), були адсорбовані на призмах $\mathrm{CaF}_{2}$ (Crystran) 3 використанням методу довільного злиття ліпідних везикул з утворенням так званих ліпідних бішарів на твердій основі (SSLBs). Модельні мембрани були досліджені за допомогою КСПЧ на межі розділу тверде тіло/вода.

Результати. Відгук КСПЧ вимірювали між $3600 \mathrm{~cm}^{-1}$ і $2800 \mathrm{~cm}^{-1}$, де проявляються ОН-валентні коливання молекул води. Інтенсивність КСПЧ максимуму піку ОН при $3125 \mathrm{~cm}^{-1}$ реєструвалася під час адсорбції ліпідних везикул на поверхні і дозволила дізнатися про зміни заряду на міжфазній межі внаслідок адсорбції модельних мембран. Сигнал КСПЧ вказує на те, що організація води при від’ємному заряді на ліпідних межах була більшою, ніж при позитивному, i досягала найвищого значення у природних кардіоліпінових шарів E. coli. Крім того, коли повний склад природних ліпідів був невідомий, характер відповіді КСПЧ дозволяв встановити характеристики заряду відповідних міжфазних меж ліпідів.

Висновки: КССЧ сигнал води дозволив оцінити заряд синтетичних і природних ліпідних бішарів в чистій воді, тим самим проклавши шлях до використання КСПЧ сигналу води в якості нового діагностичного інструменту для ідентифікації меж ліпідів.

КЛЮЧОВІ СЛОВА: вода; ліпідні мембрани; нелінійна оптика; підсумовування частоти; коливальна спектроскопія.

\section{МЕЖФАЗНАЯ ВОДА В СИНТЕТИЧЕСКИХ И ПРИРОДНЫХ ЛИПИДНЫХ БИСЛОЯХ ПО ДАННЫМ КОЛЕБАТЕЛЬНОЙ СПЕКТРОСКОПИИ С СУММИРОВАНИЕМ ЧАСТОТЫ \\ Ф. Kecce}

Лаборатория лазеров и спектроскопии, Институт структурированного вещзества Намюра,

Научно-исследовательский институт естественных наук Намюра,

Университет Намюра, ул. Брюссельская, 61, Намюр, В-5000, Бельгия

Актуальность. Вода играет решающую роль в протекании биологических процессов на липидных межфазных границах, поэтому существует огромный интерес к изучению поведения воды вблизи поверхности мембран. На заряженных межфазных границах диполи воды образуют организованный слой. Зондирование такого тонкого межфазного слоя, находящегося между макроскопическим объемным окружением, является реальной проблемой. Колебательная спектроскопия с суммированием частоты (КССЧ) является по существу специфичной к межфазным границам и уже доказала, что является идеальным инструментом для исследования модельных мембран и окружающей их воды.

Цель работы. Цель данной работы - измерить методом КССЧ колебательный отклик межфазной воды вокруг различных модельных мембран, от самых простых синтетических липидов до более сложных природных липидов, чтобы использовать его в качестве диагностического сигнала, способного различать поверхность раздела липидного бислоя по свойствам ее заряда.

Материалы и методы. Липидные бислои, изготовленные из синтетических или природных липидов (Avanti Polar Lipids), были адсорбированы на призмах $\mathrm{CaF}_{2}$ (Crystran) с использованием метода самопроизвольного слияния липидных везикул с образованием так называемых липидных бислоев на твердой подложке (SSLBs). Модельные мембраны были исследованы с помощью КССЧ на границе раздела твердое тело/вода.

Результаты. Отклик КССЧ измеряли между $3600 \mathrm{~cm}^{-1}$ и $2800 \mathrm{~cm}^{-1}$, где проявляются ОН-валентные колебания молекул воды. Интенсивность КССЧ максимума пика ОН при $3125 \mathrm{~cm}^{-1}$ регистрировалась во время адсорбции липидных везикул на поверхности и позволяла узнать об изменениях заряда на границе раздела вследствие адсорбции модельных мембран. Сигнал КССЧ указывает на то, что организация воды при отрицательном заряде на липидных границах была больше, чем при положительном, и достигала наивысшего значения у природных кардиолипиновых слоев E. coli. Кроме того, когда полный состав природных липидов был неизвестен, характер ответа КССЧ позволял установить характеристики заряда соответствующих межфазных границ липидов.

Выводы: КССЧ сигнал воды позволил оценить заряд синтетических и природных липидных бислоев в чистой воде, тем самым проложив путь к использованию КССЧ сигнала воды в качестве нового диагностического инструмента для идентификации границ липидов.

КЛЮЧЕВЫЕ СЛОВА: вода; липидные мембраны; нелинейная оптика; суммирование частоты; колебательная спектроскопия. 
Interfacial water at synthetic and natural lipid bilayers probed by vibrational...

Biological interfaces and water make an indivisible pair, where the physicochemical properties and biological processes at biointerfaces are intimately linked to the structure and the behavior of water.

Among biological interfaces, the cell membrane is an ultimate interfacial system, because it is that two-dimensional region making the barrier between the inner and the outer cell environments. Many physiological processes occurring within the membrane barrier are carried and triggered by water, such as protons and ions transport, metabolites adsorption and translocation, or proteins folding, for instance $[1,2]$. This is why the properties and the behavior of this small and ubiquitous molecule have attracted the interest of researchers from different disciplines, from biology and medicine, to chemistry and physics.

A crucial point is that water close to biological interfaces is far from behaving as bulk disordered water, while it owns specific order and organization [3, 4]. Indeed, upon an electrical potential, such as the onegenerated by charged interfaces, water dipoles orient along preferential directions, thus forming an organized layer of water, as long as the electric field associated to the electrical potential is non-vanishing. The degree of organization and the thickness over which the organization take place will depend on the physicochemical properties of the interface, i.e., net molecular charge, surface charge density, molecular orientation, structure, and hydrophilicity, as well as $\mathrm{pH}$ and ionic strength of the liquid medium [5]. Whatever the process that would modify the interfacial properties, this latter may affect the organization of such a water layer.

The structure, the order and the behavior of interfacial water close to membrane interfaces have been extensively modelled with theoretical approaches, while its direct measure remained long-time unavailable. This limitation has been definitely encompassed with the advent of vibrational sum frequency generation (SFG) spectroscopy. Indeed, being based on a second order nonlinear optical (NLO) phenomenon, which is possible only in noncentrosymmetric environments - like anisotropic bulk materials or interfacial systems, $[6,7]$ SFG spectroscopy is ideally able to probe an organized layer of water, because this latter owns a non-centrosymmetric structure, contrary to bulk water. Moreover, SFG spectroscopy probes molecular vibrations, so that it provides the chemical fingerprint of interfacial water. These skills made SFG spectroscopy a favorite technique to probe water close to membrane systems [8-22]. The investigation of the SFG response around membrane models demonstrated that the surrounding structure of water strongly depends on the physicochemical properties of the interface, and so is tuned by the interactions and the processes occurring within these biological systems.

Here, we will probe the vibrational NLO response of interfacial water at different models of lipid membranes, made of synthetic or natural lipids, supported on $\mathrm{CaF}_{2}$. Indeed, the average charge properties of the interfaces trigger the signal of interfacial water accordingly. The goal is testing the potentiality of using the SFG response of interfacial water to identify the underlying lipid bilayer, and then explore new solutions to make SFG spectroscopy a biodiagnostic tool.

\section{MATERIALS AND METHODS}

Lipid bilayers. We prepared lipid bilayers adsorbed on $\mathrm{CaF}_{2}$ prisms from different lipids Figure 1), namely1,2-dihexanoyl-sn-glycero-3-phosphoethanolamine (6:0 PE or DHPE), 1,2dipalmitoyl-sn-glyero-3-phosphoethanolamine (16:0PE or DPPE), 1,2-dioleoyl-sn-glycero-3phosphoethanolamine (18:1 $\Delta$ 9-Cis PE or DOPE), 1,2-dioleoyl-sn-glycero-3-phospho-Lserine (18:1 PS or DOPS), 1,2-dioleoyl-sn-glycero-3-[phospho-rac-(3-lysyl(1-glycerol))] 


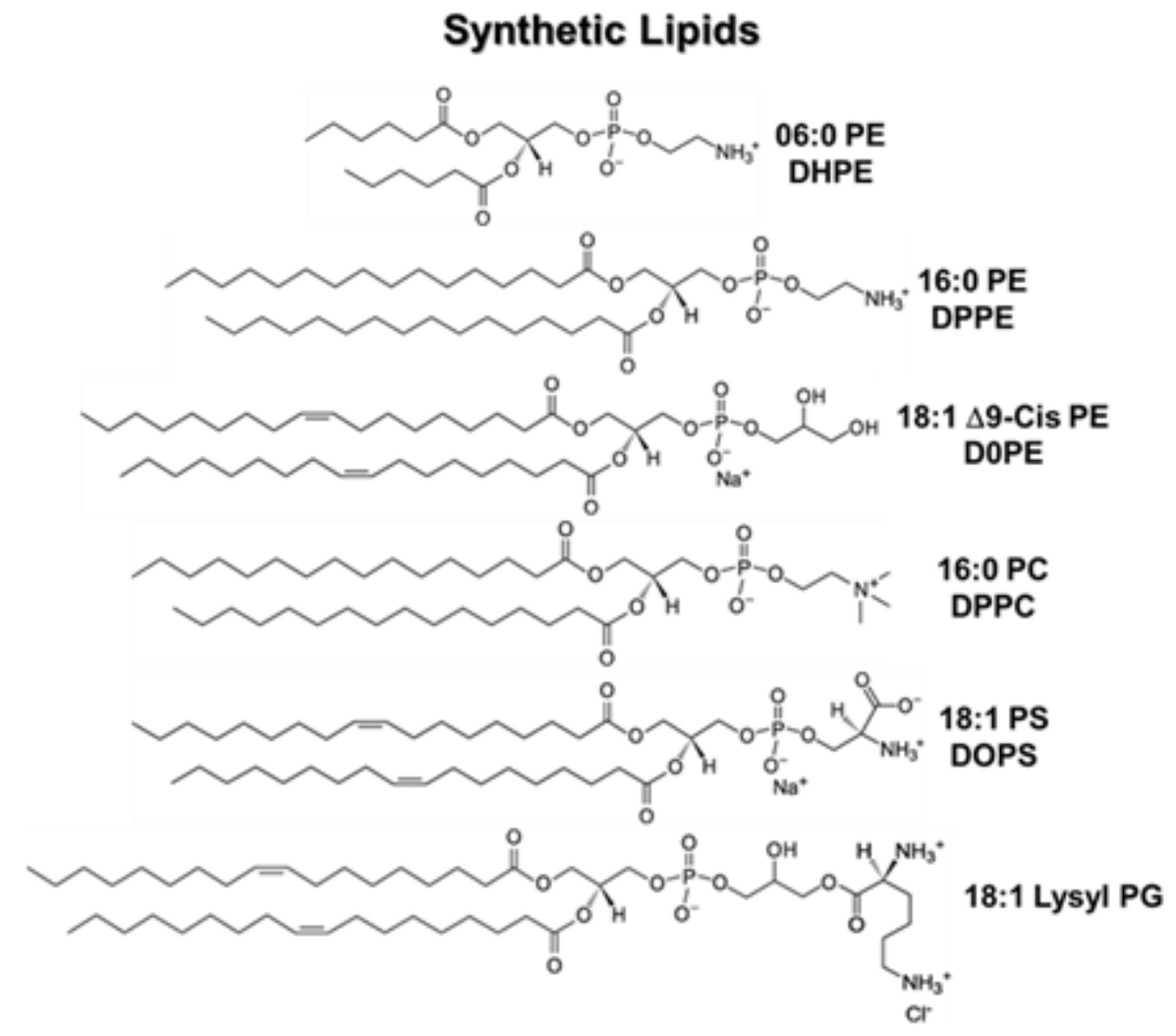

Natural Lipids

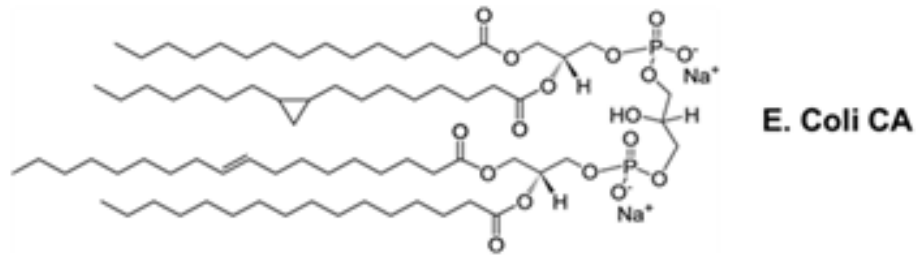

E. Coli Total Lipid Extract (ETLE)

Yeast Total Lipid Extract (YTLE)

Fig. 1. Chemical structures of the lipid compounds used to prepare SSLBs as obtained from Avanti ${ }^{\circledR}$ Polar Lipids supplier (for E. coli Total Lipid Extract and Yeast Total Lipid Extract full compositions refers to Avanti ${ }^{\circledR}$ Polar Lipids website).

(18:1 Lysyl PG), E. coli cardiolipin (E. coli CA), E. coli total lipid extract (ETLE) and yeast total lipid extract (YTLE). All lipid molecules were purchased from Avanti ${ }^{\circledR}$ Polar Lipids, Inc. (Alabaster, Alabama, USA). SSLBs were obtained through the method of the spontaneous fusion of lipid vesicles on $\mathrm{CaF}_{2}$ (Crystran, UK). $\mathrm{CaF}_{2}$ prisms were cleaned by immersion in a diluted piranha solution $\left(\mathrm{H}_{2} \mathrm{SO}_{4}: \mathrm{H}_{2} \mathrm{O}_{2}, 2: 1\right.$ diluted 10 times) for 1 minute and then rinsed thoroughly with Milli-Q water $(18.2 \mathrm{M} \Omega . \mathrm{cm}, \mathrm{pH}=5.5)$. Lipid vesicles were prepared by i) solubilizing $2 \mathrm{mg}$ of lipid powder in $300 \mu \mathrm{L}$ of chloroform $\left(\mathrm{CHCl}_{3}\right)$, ii) evaporating $\mathrm{CHCl}_{3}$ under $\mathrm{N}_{2}$ flow, and iii) adding $1 \mathrm{~mL}$ of Milli-Q water. The obtained solutions were sonicated for $10 \mathrm{~min}$ and then centrifuged for $10 \mathrm{~min}$ at $6000 \mathrm{rpm}$. The vesicle solutions were injected into a Teflon cell containing $1 \mathrm{~mL}$ of Milli-Q water $\left(18.2 \mathrm{M} \Omega \mathrm{cm}^{-1}\right)$ and holding the $\mathrm{CaF}_{2}$ substrate, so that the vesicles concentration during the fusion process at the surface were half of the native concentration. After 3 hours of contact with the prism, 
Interfacial water at synthetic and natural lipid bilayers probed by vibrational...

SSLBs were expected to be formed [21, 23, 24]. The remaining vesicles in solution were fully removed by exchanging the solution with Milli-Q water. This procedure was carried out by adding $0.5 \mathrm{~mL}$ of Milli-Q water and then removing $0.5 \mathrm{~mL}$ of the diluted solution. These steps were repeated at least 20 times in order to leave the SSLBs in contact with an almost pure Milli-Q water solution.

SFG setup. The SFG response of water at the interface was recorded with a homemade SFG spectrometer. Two pulsed incident beams (15 ps, $25 \mathrm{~Hz})$, namely, an IR beam tuned between $3600-2800 \mathrm{~cm}^{-1}$ (average power $=25 \mathrm{~mW}$ ) and a visible (Vis) beam fixed at $532 \mathrm{~nm}$ (or $18796.99 \mathrm{~cm}^{-1}$, average power $=10 \mathrm{~mW}$ ), were superimposed spatially and temporally at the $\mathrm{CaF}_{2}$ /water interface in a total internal reflection geometry through the prism (Fig. 2). An SFG beam was generated with a frequency equal to the sum of the two incident beam frequencies. All measurements were performed at room temperature $\left(22.5^{\circ} \mathrm{C}\right)$. To perform comparisons between samples, the SFG responses were normalized by the IR and Vis beams, and by the SFG response of the neat $\mathrm{CaF}_{2} /$ water interface, which was measured before each lipid bilayer adsorption. All experiments were repeated at least twice.

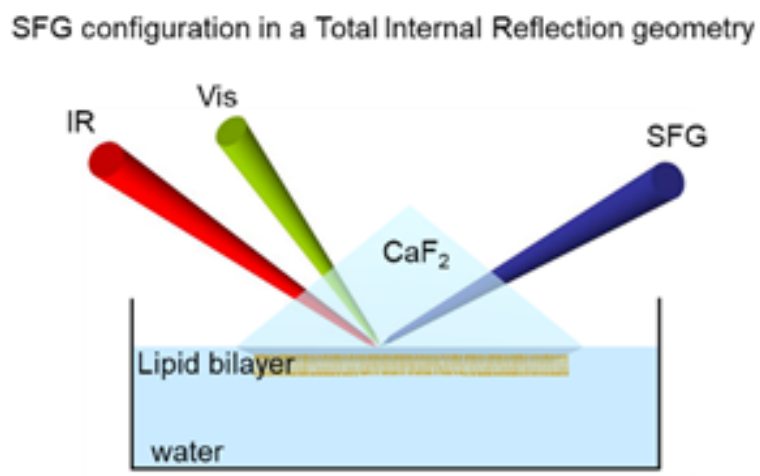

Fig. 2. Schematic representation of a SFG measurement at the $\mathrm{CaF}_{2} /$ lipid/water interface in a Total Internal Reflection (TIR) geometry of the incident IR and Vis beams and of the generated SFG beam.

Theoretical background. Vibrational SFG spectroscopy is based on a $2^{\text {nd }}$ order NLO process, in which the three photon mixing process enables probing the vibrational response of chemical groups in a nonlinear regime. In a SFG process (Fig. 2), one tunable infrared (IR) and one fixed visible (Vis) beams are focused at the interface, where their interaction with the second order susceptibility $\left(\chi^{(2)}\right)$ of matter generates a newbeam at their sum frequency $\left(\mathrm{SFG}, \omega_{S F G}=\omega_{I R}+\omega_{V i S}\right)$. The key selection rule of $2^{\text {nd }}$ order NLO processes is that the $\chi^{(2)}$ susceptibility tensor, in the dipole approximation, is zero for centrosymmetric media, while it is non-zero where the inversion symmetry is broken, like at interfaces. It follows that SFG spectroscopy provides the vibrational signature of interfacial regions only, while it is insensitive to their surrounding bulk environments, either solid, liquid or gaseous.

In addition to the interfacial sensitivity, the SFG response of a vibrational mode of the interface requires this latter is simultaneously IR and Raman active. Definitely, once the tunable IR beam matches an SFG active vibrational mode of the interface, then there is an enhancement of the SFG response, accordingly to the following relations:

$$
I_{S F G} \propto\left|\chi_{N R}^{(2)}+\chi_{R}^{(2)}\right|^{2} I_{V i S} I_{I R}
$$

where $I_{V i s}$ and $I_{I R}$ are the intensities of the incident visible and infrared beams, $\chi_{N R}^{(2)}$ is the non-resonant part of the effective second order susceptibility that can eventually come from the electronic properties of the close bulk environment. The $\chi_{R}^{(2)}$ resonant contribution is related to the active molecular vibrations as follows: 


$$
\begin{gathered}
\chi_{R, i j k}^{(2)} \propto \sum_{q} \frac{A_{q, i j k}}{\omega_{q}-\omega_{I R}-i \Gamma_{q}}, \\
A_{q, i j k} \propto N \sum_{l m n}<T_{l m n}^{i j k}>\beta_{l m n}^{(2)}, \\
\beta_{l m n}^{(2)} \propto \frac{\partial \alpha_{l m}}{\partial q} \frac{\partial \mu_{n}}{\partial q},
\end{gathered}
$$

where $\omega_{q}$ and $\omega_{I R}$ are the frequencies of the $q^{t h}$ molecular mode and of the incident infrared beam, respectively, $\Gamma_{q}$ is the damping factor, and $A_{q, i j k}$ is the oscillator strength of the $q^{\text {th }}$ molecular mode, which is the macroscopic response $N$ individual oscillators for which the molecular second order hyperpolarisability $\beta_{l m n}^{(2)}$ is linked to the variations of the dipole moment and of the polarizability. $T_{l m n}^{i j k}$ rotates the molecular coordinates $l m n$ into the interface coordinates $i j k$, and the braket indicates the average over the molecular orientation distribution and $\frac{\partial \mu_{n}}{\partial q}$ and $\frac{\partial \alpha_{l m}}{\partial q}$ are the variation of the dipole moment (IR activity) and of the polarizability (Raman activity), respectively, of the $q^{\text {th }}$ vibrational mode [25, 26].

In summary, the strict selection rules - that is $\chi_{R}^{(2)} \neq 0, \frac{\partial \mu}{\partial q} \neq 0$ and $\frac{\partial \alpha}{\partial q} \neq 0,-$ combined to the $N^{2}$ dependence of the SFG intensity and to the coherent nature of the SFG process, make SFG spectroscopy ideally able to probe a thin interfacial layer of water molecules close to an interface, with a chemical selectivity.

\section{RESULTS AND DISCUTION}

The SFG spectrum of the neat $\mathrm{CaF}_{2} /$ water interface (Fig. 3, top) was systematically recorded before adsorption of lipid vesicles. The broad band centered at $3125 \mathrm{~cm}^{-1}$ is due to

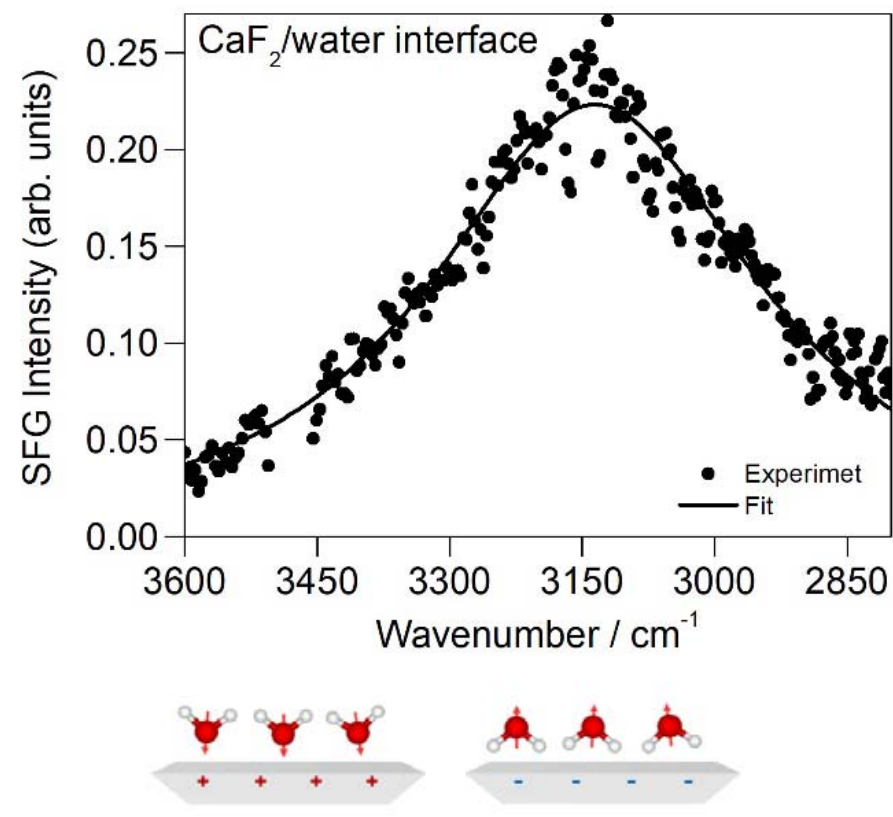

Fig. 3. SFG spectrum (top) of the neat $\mathrm{CaF}_{2} /$ water interface, and schematic and simplified representation (bottom) of the water dipole orientation, with the $\mathrm{H}$ atoms pointing out or towards the interface, depending on the sign of the charged interface (positive charge on the left side, and negative charge on the right side).

$\mathrm{OH}$ stretching vibrations of interfacial water [20-23]. Indeed, the surface of $\mathrm{CaF}_{2}$ is known to own a slightly positive charge (its zeta potential in pure water is about $+20 \mathrm{mV}$ ), which drives the organization of a thin layer of water, possibly with the $\mathrm{H}$ atoms pointing out from the surface (as shown in the simplified picture in the bottom of Fig. 3, left part) [27-29]. The corresponding maximum SFG intensity was about 0.22 arbitrary units (arb. units) (Table 1). 
Interfacial water at synthetic and natural lipid bilayers probed by vibrational...

This value will represent the reference signal to which all following $\mathrm{CaF}_{2} / \mathrm{lipid} / \mathrm{water}$ interfaces will refer.

Table 1. SFG maximum signal at the $\mathrm{CaF}_{2} /$ water and lipids/water interfaces recorded at $3125 \mathrm{~cm}^{-1}$. The error bars are estimated to $\pm 15 \%$.

\begin{tabular}{|c|c|}
\hline Interface & SFG intensity (arb. units) \\
\hline $\mathrm{CaF}_{2} /$ water & 0.22 \\
\hline $\mathrm{CaF}_{2} / \mathrm{DHPE} /$ water & 0.20 \\
\hline $\mathrm{CaF}_{2} / \mathrm{DPPE} /$ water & 0.18 \\
\hline $\mathrm{CaF}_{2} / \mathrm{DOPS} /$ water & 1.50 \\
\hline $\mathrm{CaF}_{2} / \mathrm{DOPG} /$ water & 0.60 \\
\hline $\mathrm{CaF}_{2} /$ E. coli $\mathrm{CA} /$ water & 3.75 \\
\hline $\mathrm{CaF}_{2} / \mathrm{ETLE} /$ water & 0.25 \\
\hline $\mathrm{CaF}_{2} / \mathrm{YTLE} /$ water & 0.31 \\
\hline
\end{tabular}

The adsorption and fusion of lipid vesicles at the $\mathrm{CaF}_{2} /$ water interface was monitored in real time, by recording the SFG intensity at $3125 \mathrm{~cm}^{-1}$ for 3 hours of adsorption. Then, the remaining lipid vesicles in solution were removed, and the SFG maximum intensity of the $\mathrm{CaF}_{2} / \mathrm{lipid} /$ water interfaces was measured.

\section{Synthetic Lipid Layers}

Neutral zwitterion PE lipids. DHPE, DPPE, DOPE are all neutral zwitterion lipids. Their difference is in the composition of the hydrophobic chains. DHPE holds two full saturated aliphatic chains (i.e. 6 aliphatic carbon atoms/chain). The adsorption of DHPE vesicles on $\mathrm{CaF}_{2}$ did not modify substantially the interfacial charge properties, as the signal of water remained almost constant along the adsorption process ( $0.2 \mathrm{arb}$. units). This is in agreement with both the neutral charge carried by the lipid molecule, and with the weak charge screening effect induced by short aliphatic chains. Compared to DHPE, DPPE has longer aliphatic chains (16 C atoms/chain), made also of all saturated bonds. The adsorption of DPPE decreased the water signal from 0.22 at the neat $\mathrm{CaF}_{2}$ interface to 0.10 at the DPPE interface, indicating a weak screening of the interfacial charges by the lipid layer, whilst the lipid interface remained positively charged.

DOPE is composed of two aliphatic chains, almost as long as DPPE (18 carbon atoms/chain), while it carries one unsaturated bond in each aliphatic chain. The adsorption of DOPE occurred with only slightly decreasing the SFG signal of water to 0.18 arb. units. The different behavior of DPPE and DOPE in the screening effect can be attributed to the saturated/unsaturated bonds in the aliphatic chains, which trigger the conformational organization of the lipid layers. Indeed, the presence of unsaturated bonds affects the phase transition temperature $\left(\mathrm{T}_{\mathrm{m}}\right)$ of lipids [30], so that DOPE $\left(\mathrm{T}_{\mathrm{m}}=-16^{\circ} \mathrm{C}\right)$ is in a liquid-like phase at ambient temperature, while the full saturated bonds of the DPPE $\left(\mathrm{T}_{\mathrm{m}}=+63^{\circ} \mathrm{C}\right)$ tails make the corresponding lipid layer in a gel-like phase. The resulting bilayer structures show a more densely packed organization for DPPE than for DOPE, with the consequence that DPPE drives a larger charge screening than DOPE.

Negatively PS and positively Lysyl PG charged lipids. DOPS and Lysyl PG are negative and positive charged lipids, respectively, with one net charge per molecule. DOPS holds two negative and one positive charges, while DOPG holds one negative and two positive charges, which are localized on the polar heads, respectively. Both lipids have the same aliphatic chains, with one unsaturated bond in each aliphatic chain, giving rise to a liquid-like conformation of the corresponding bilayers at room temperature. Starting from the intensity of the $\mathrm{CaF}_{2} /$ water signal (0.22 arb. units), once DOPS vesicles were injected in the cell to 
adsorb and fuse on the $\mathrm{CaF}_{2}$ surface and form a lipid bilayer, the SFG intensity decreased to zero in a few seconds, then increased to 1.50 arb. units in the next minute, and remained stable at this value for the next $3 \mathrm{~h}$. The passing from zero of the SFG intensity correspond to the flip-flop of water molecules from the up to the down conformation (Fig. 3, bottom) [12, 31]. Indeed, DOPS vesicles carried their negative charge close to the $\mathrm{CaF}_{2}$ surface, and screened their positive charge. The further saturation of the surface by DOPS vesicles led to a strongly negatively charged interface, so that the SFG signal increased back, which correspond to an organisation of the water dipoles close to the lipid interface. A different behavior was observed during the adsorption of Lysyl PG vesicles at the $\mathrm{CaF}_{2} /$ water interface. Here, the SFG signal showed a fast increase of the SFG signal to 0.60 arb. units directly, without passing from zero, in agreement with the positive net charge carried by the lipids polar heads, which is of the same sign of the neat $\mathrm{CaF}_{2}$ surface. Definitely, at the DOPS/water interface, water dipoles are expected to be oriented with a down conformation (Fig. 3 bottom right), while for Lysyl PG/water interface they are expected to be predominantly oriented with an up conformation (Fig. 3, bottom left).

\section{Natural Lipid Layers}

Going from the easiest model membranes made of mono-component layers of synthetic lipids of known chemical composition towards more representative models of real systems requires facing that the full composition of the lipid layers is unknown.

E. coli cardiolipin. E. coli $\mathrm{CA}$ is a mixture of different CA structures, all holding the CA polar head, carrying two net negative charges, and different hydrophobic chains, which are in the amount of four per molecule. Starting from a SFG intensity of $0.22 \mathrm{~V}$ at the neat $\mathrm{CaF}_{2} /$ water interface, the injection of $E$. coli CA vesicles in the liquid cell decreased the SFG intensity to zero in less than 10 minutes, and then this latter increased back and reached a value as high as $3.75 \mathrm{arb}$. units after $3 \mathrm{~h}$. This behavior indicates that $E$. coli vesicles screened the initially positive charge of $\mathrm{CaF}_{2}$, and then the corresponding lipid bilayer provided a strongly negative character to the interface, which drove a higher organization of interfacial water. This is possibly due to the structure of CA compounds, which, due to the presence of four hydrophobic chains per molecule owing strong intermolecular interactions, give rise to densely packed structures, leading to a higher density of charges per surface area. Moreover, so densely packed films led to highly organized structures, where the polar heads are predominantly oriented in a preferential direction, which may favor a large alignment of water close to the lipid interface.

Total lipid extracts: ETLE and YTLE. E. coli total lipid extract is composed of different neutral and charged lipids. The known fraction of ETLE (as provided by the supplier Avanti Polar Lipids), which account for the $82.4 \%$ of the total composition, exhibits an average charge of the lipid composition that is negatively charged, while the remaining $17.6 \%$ fraction was unknown. The injection of ETLE vesicles at $\mathrm{CaF}_{2} /$ water interface induced a decreased of the SFG intensity to zero, and then an increase up to $0.25 \mathrm{arb}$. units in only one minute. This behavior is in agreement with a very fast screening of the positive charge of $\mathrm{CaF}_{2}$ by ETLE vesicles, which inverted the sign the interfacial charges from positive to negative. This statement enabled unravelling that an inversion of the orientation of the water dipoles occurred, which testified for an average negatively charged character of the ETLE lipid interface.

Similarly, the exact charge of YTLE was also unknown (see the YTLE composition as provided by Avanti Polar Lipids). The injection of YTLE vesicles decreased the initial SFG intensity to zero, and then this latter increased back up to 0.31 arb. units in the next 3 hours. This behavior suggests an average negative charge of the YTLE lipid layer, which triggered an 
Interfacial water at synthetic and natural lipid bilayers probed by vibrational...

inversion of orientation of the water dipoles from the $\mathrm{CaF}_{2} /$ water interface to the $\mathrm{CaF}_{2} /$ YTLE/water interface.

\section{CONCLUSIONS}

The SFG response of water wasmeasured at neutral, negative and positive monocomponent lipid bilayers, respectively, andshowed that the highestsignal, corresponding to a high degree of organisation, was reached at the DOPS negative lipid interface. At natural lipid layers interfaces, the SFG response of E. coli Cardiolipin layers indicated an impressive organization of water close to the interface, since the SFG signal increased by two times larger than at the negative mono-component lipid interface. These behaviors enabled estimatingthe average charge properties of two natural lipids compounds, namely E. coli total lipid extract and yeast total lipids extracts, whose full composition was unknown. The SFG response during the adsorption of the corresponding vesicles onto the surface demonstrated that these lipid layer interfaceswere in average negatively charged, with a sligthly higher organisation of water at the YTLE than at the ETLE interface.By using synthetic lipid layers of known composition as reference signals, it has been then possible to unravel the average charge properties of natural lipid interfaces. The possibility to distinguish lipid interfaces by the signal of their organized water environment represents a possible solution to be explored for developing new, innovative and label-free biodevices.

\section{ACKNOWLEDGMENT}

The author thanks the National Belgian Fund for the Scientific Research F.R.S.-FNRS, the NATO SPS Program (under the grant number G5292 "Biohazards) for financial support, and the "Lasers, Optics and Spectroscopies" technological platform (LOS) of University of Namur for instrumental and technical support.

\section{CONFLICT OF INTEREST}

The author reports that there is no conflict of interest.

F. Cecchet (iD https://orcid.org/0000-0001-7740-3383

\section{AUTHOR'S ORCID ID}

\section{REFERENCES}

1. Disalvo EA, Pinto OA, Martini MF, Bouchet AM, Hollmanna A, Frías MA. Functional role of water in membranes updated: A tribute to Träuble. Biophys Biochim Acta Biomembr. 2015;1848(7):1552-62. https://doi.org/10.1016/j.bbamem.2015.03.031

2. Ball P. Water as an active constituent in cell biology. Chem Rev. 2008;108(1):74-108. https://doi.org/10.1021/cr068037a

3. Fayer MD, Levinger NE. Analysis of water in confined geometries and at interfaces. Annu Rev Anal Chem. 2010;3:89-107. https://doi.org/10.1146/annurev-anchem-070109-103410

4. Gun'ko VM, Turov VV, Bogatyrev VM, Zarko VI, Leboda R, Goncharuk EV, Novza AA, Turov AV, Chuiko AA. Unusual properties of water at hydrophilic/hydrophobic interfaces. Adv Colloid Interface Sci. 2005;118(1-3):125-72. https://doi.org/10.1016/j.cis.2005.07.003

5. Sanders SE, Vanselous H, Petersen PB. Water at surfaces with tunable surface chemistries. J Phys Condens Matter. 2018;30:113001. https://doi.org/10.1088/1361-648X/aaacb5

6. Shen YR. Surface properties probed by second-harmonic and sum-frequency generation. Nature. 1989;337:519-25. https://doi.org/10.1038/337519a0

7. Shen YR. Fundamentals of sum-frequency spectroscopy. Cambridge University Press, Cambridge; 2016. https://doi.org/10.1017/CBO9781316162613

8. Adhikari A, Re S, Nishima W, Ahmed M, Nihonyanagi S, Klauda JB, et al. Water orientation at ceramide/water interfaces studied by heterodyne-detected vibrational sum frequency generation spectroscopy 


\section{F. Cecchet}

and molecular dynamics simulation. J Phys Chem C. 2016;120(41):23692-7.

https://doi.org/10.1021/acs.jpcc.6b08980

9. Allen HC, Casillas-Ituarte NN, Sierra-Hernández MR, Chen X, Tang CY. Shedding light on water structure at air-aqueous interfaces: Ions, lipids, and hydration. Phys Chem Chem Phys. 2009;11(27):5538-49. https://doi.org/10.1039/b901209e

10. Cyran JD, Backus EHG, Nagata Y, Bonn M. Structure from dynamics: vibrational dynamics of interfacial water as a probe of aqueous heterogeneity. J Phys Chem B. 2018;122(14):3667-79. https://doi.org/10.1021/acs.jpcb.7b10574

11. Ishiyama T, Terada D, Morita A. Hydrogen-bonding structure at zwitterionic lipid/water interface. J Phys Chem Lett. 2016;7(2):216-20. https://doi.org/101021/acsjpclett5b02567

12. Mondal JA, Nihonyanagi S, Yamaguchi S, Tahara T. Three distinct water structures at a zwitterionic lipid/water interface revealed by heterodyne-detected vibrational sum frequency generation. J Am Chem Soc. 2012;134(18): 7842-50. https://doi.org/10.1021/ja300658h

13. Nojima Y, Suzuki Y, Yamaguchi S. Weakly Hydrogen-bonded water inside charged lipid monolayer observed with heterodyne-detected vibrational sum frequency generation spectroscopy. J Phys Chem C. 2017;121(4):2173-80. https://doi.org/10.1021/acs.jpcc.6b09229

14. Ohto T, Backus EHG, Hsieh CS, Sulpizi M, Bonn M, Nagata Y. Lipid carbonyl groups terminate the hydrogen bond network of membrane-bound water. J Phys Chem Lett. 2015;6(22)4499-503. https://doi.org/10.1021/acs.jpclett.5b02141

15. Re S, Nishima W, Tahara T, Sugita Y. Mosaic of water orientation structures at a neutral zwitterionic $\mathrm{lipid} /$ water interface revealed by molecular dynamics simulations. J Phys Chem Lett. 2014;5(24):4343-8. https://doi.org/10.1021/jz502299m

16. Roy S, Gruenbaum SM, Skinner JL. Theoretical vibrational sum-frequency generation spectroscopy of water near lipid and surfactant monolayer interfaces. J Chem Phys. 2014;141:18C502. https://doi.org/10.1063/1.4895546

17. Singh PC, Inoue KI, Nihonyanagi S, Yamaguchi S, Tahara T. Femtosecond hydrogen bond dynamics of bulk-like and bound water at positively and negatively charged lipid interfaces revealed by 2D HD-VSFG spectroscopy. Angew Chem Int Ed Engl. 2016;55:10621-5. https://doi.org/10.1002/anie.201603676

18. Sovago M, Campen RK, Wurpel GWH, Müller M, Bakker HJ, Bonn M. Vibrational response of hydrogenbonded interfacial water is dominated by intramolecular coupling. Phys Rev Lett. 2008;100(17):173901. https://doi.org/10.1103/PhysRevLett.100.173901

19. Sovago M, Vartiainen E, Bonn M. Observation of buried water molecules in phospholipid membranes by surface sum-frequency generation spectroscopy. J Chem Phys. 2009;131(16):161107. https://doi.org/10.1063/1.3257600

20. Toledo-Fuentes X, Lis D, Cecchet F. Structural changes to lipid bilayers and their surrounding water upon interaction with functionalized gold nanoparticles. J Phys Chem C. 2016;120(38):21399-409. https://doi.org/10.1021/acs.jpcc.6b05460

21. Molinaro C, Cecchet F. Label-free, quantitative and sensitive detection of nanoparticle/membrane interaction through the optical response of water. Sens Actuators B Chem. 2019;289:169-74. https://doi.org/10.1016/j.snb.2019.03.006

22. Lis D, Cecchet F. Unique vibrational features as a direct probe of specific antigen-antibody recognition at the surface of a solid-supported hybrid lipid bilayer. Chem Phys Chem. 2016;17(17):2645-9.

https://doi.org/10.1002/cphc.201600419

23. Toledo-Fuentes X, Molinaro C, Cecchet F. Interfacial charges drive the organization of supported lipid membranes and their interaction with nanoparticles. Colloids Surf B Biointerfaces. 2018;172:254-61. https://doi.org/10.1016/j.colsurfb.2018.08.018

24. Keller CA, Glasmästar K, Zhdanov VP, Kasemo B. Formation of supported membranes from vesicles. Phys Rev Lett. 2000;84(23):5443-6. https://doi.org/10.1103/PhysRevLett.84.5443

25. Cecchet F, Lis D, Guthmuller J, Champagne B, Caudano Y, Silien C, Mani AA, Thiry PA, Peremans A. Orientational analysis of dodecanethiol and p-nitrothiophenol SAMs on metals with polarization-dependent SFG spectroscopy. Chem Phys Chem. 2010;11(3):607-15. https://doi.org/10.1002/cphc.200900733

26. Cecchet F, Lis D, Guthmuller J, Champagne B, Fonder G, Mekhalif Z, Caudano Y, Mani AA, Thiry PA, Peremans A. Theoretical calculations and experimental measurements of the vibrational response of p-NTP SAMs: an orientational analysis. J Phys Chem C. 2010;114(9):4106-13. https://doi.org/10.1021/jp911836k

27. Miller JD, Fa K, Calara JV, Paruchuri VK. The surface charge of fluorite in the absence of surface carbonation. Colloids Surf A Physicochem Eng Asp. 2004;238(1-3):91-7.

https://doi.org/10.1016/j.colsurfa.2004.02.030 
28. Lis D, Backus EHG, Hunger J, Parekh SH, Bonn M. Liquid flow along a solid surface reversibly alters interfacial chemistry. Science. 2014;344(6188):1138-42. https://doi.org/10.1126/science.1253793

29. Khatib R, Backus EHG, Bonn M, Perez-Haro M-J, Gaigeot M-P, Sulpizi M. Water orientation and hydrogen-bond structure at the fluorite/water interface. Sci Rep. 2016;6:24287. https://doi.org/10.1038/srep24287

30. Silvius JR. Thermotropic phase transitions of pure lipids in model membranes and their modifications by membrane proteins. In: Jost PC, Griffith OH, editors. Lipid-Protein Interactions. V.2. John Wiley \& Sons, Inc., New York, 1982. p. 239-81.

31. Dreier LB, Nagata Y, Lutz H, Gonella G, Hunger J, Backus EHG, Bonn M. Saturation of charge-induced water alignment at model membrane surfaces. Sci Adv. 2018;4(3):7415.

https://doi.org/10.1126/sciadv.aap7415 